\title{
Manufacturer's Responsibility for Inclusion of Halal Labels on Processed Food Products that are not through Certification in Indonesia
}

\author{
Siti Malikhatun Badriyah ${ }^{1}$, Budi Ispriyarso ${ }^{2}$, R. Suharto ${ }^{3}$, Marjo $^{4}$, \\ Muhammad Haidar Fakhri Allam ${ }^{5}$ \\ \{sitimalikhatun@live.undip.ac.id $\left.{ }^{1}\right\}$ \\ Universitas Diponegoro, Indonesia ${ }^{1,2,3,4,5}$
}

\begin{abstract}
The problem of this research is how the producer is responsible for including halal labels on processed food products. This study aims to find evidence regarding the responsibility of producers for halal labeling on processed food and the legal consequences if the inclusion of the halal label does not comply with the standard. The research method used is a normative juridical approach to identify and analyze the responsibility of producers in the inclusion of halal food products that do not go through the certification process. The theory used to analyze is the concept of producer responsibility, the concept of unlawful acts, the theory of the work of law in society to analyze the responsibility of producers in the inclusion of halal labels on processed food products. The results showed that producers are obliged to carry out halal certification for their products as business actors.
\end{abstract}

Keywords: Processed Food, Halal Certification, Responsibility, Acts Against the Law

\section{Introduction}

Halal food products are very important for the life of the Muslim community. Therefore, every Muslim must take care of himself to consume halal food. Producers should act honestly and be careful in producing food to maintain its halalness. For this reason, it is necessary to have supervision, both through statutory regulations and a food auditing institution, before food is distributed [1].

In various countries globally, halal is an important concern among consumers [2]. Currently, the halalness of food products, one of which is processed food, is vital for the Muslim community and all human beings in the world. In various countries globally, the halalness of this food product is also a serious concern. It is because food is related to primary human needs and more broadly. Food has a relationship with various aspects of community life. Halal food products are very important in the economic sector, especially with food as a culinary tourism destination. The inclusion of a halal label is a unique attraction for tourists.

The broad connection between food and various fields of life was also raised by those who discussed food security theory and policy. It is an important topic in the broader field of economic development and development studies [3]. A halal certificate is required to ensure the halalness of the product produced by the producer. Halal Product Guarantee is legal certainty of the halalness of a Product as evidenced by a Halal Certificate (Article 1 Paragraph 5 Law of the Republic of Indonesia No. 33 of 2014 concerning Halal Product Guarantee/Halal Product 
Guarantee Law). Halal Certificate is legal evidence stating the halalness of a production confirmed by the Minister of Religion. Labeling of halal food products must be carried out through a certification process first to become a guideline to ensure the halalness of a food product. Products with an official halal mark can guarantee consumers the halalness of the product in question [1][4].

In practice, there is often the inclusion of halal labels on processed food packaging but not through a certification process. Therefore, it can be detrimental to consumers who believe that packaging with the inclusion of a halal label shows the halalness of the food product. It is not confident that the product is halal because there is no test regarding the halalness of the product. The problem that arises is how the responsibility of the product towards the inclusion of halal labels on processed food products. Therefore, research on the problem of the responsibility of producers in the inclusion of halal labels on processed food products is very urgent.

The theory used to analyze is producer responsibility, the concept of illegal actions, the theory of the operation of law in society to analyze the responsibility of producers in the inclusion of halal labels on processed food products.

This study uses a normative juridical method to study various laws and regulations, legal principles, legal norms that are the basis for implementing halal certification on processed food products. In addition, this study aims to obtain an overview and analyze the responsibility of producers in the inclusion of halal labels on processed food products that are not going through the certification process.

\section{Results and Discussion}

\subsection{Labeling of Processed Food Products and Responsibilities of Producers}

The implementation of the Halal Product Guarantee (JPH), according to Article 2 of Halal Product Guarantee Law is based on protection, justice, legal certainty, accountability and transparency, effectiveness and efficiency, and professionalism. What is meant by the principle of "protection" is that in organizing JPH, the objective is to protect the Muslim community. What is meant by the principle of "justice" is that the implementation of JPH must reflect justice proportionally to every citizen. What is meant by the principle of "legal certainty" is that the implementation of JPH aims to provide legal certainty regarding the halalness of a Product proven by a Halal Certificate. What is meant by the principle of "accountability and transparency" is that every activity and the final results of the JPH activities must be accountable to the public as the holder of the highest state sovereignty by the provisions of laws and regulations. What is meant by the principle of "effectiveness and efficiency" is that the implementation of JPH is carried out with an objective orientation that is efficient and efficient and minimizes the use of resources using a fast, simple, and low cost or affordable way. Finally, what is meant by the principle of "professionalism" is that the implementation of JPH is carried out by prioritizing expertise based on competence and a code of ethics.

The implementation of JPH aims to: a) provide comfort, security, safety, and certainty of the availability of Halal Products for the public in consuming and using the Products; and b) increasing added value for Business Actors to produce and sell Halal Products (Article 3 of the Halal Product Guarantee Law).

Article 4 of Law of the Republic of Indonesia No. 33 of 2014 and Article 2 of Government Regulation of the Republic of Indonesia No. 31 of 2019 Concerning Implementation 
Regulations of Law Concerning Halal Product Guarantee Regarding Halal Product Guarantee states that products that enter, circulate and are traded in Indonesian territory are required halal certified. It shows that all business actors who import, distribute, and trade products in Indonesia's territory must carry out halal certification. Products originating from prohibited materials are exempted from the obligation to be halal certified. The product must be declared non-halal. Business Actors are required to include non-halal information on the Products. Article 3 PP Halal Product Guarantee states that halal certificates are given to Products originating from halal materials and fulfill the Halal Product Guarantee.

This halal product guarantee can guarantee legal protection for consumers. Article 4 letter c of Law No. 8 of 1999 concerning Consumer Protection states that consumer rights are the right to obtain true, clear, and honest information regarding the condition and guarantee of goods and/or services. It means that producers must provide true and honest information about their products, including a halal sign on the food product [1]. In addition to having rights, consumers also have obligations as stated in Article 5 letter an of the Consumer Protection Law, namely reading and following information instructions and procedures for using or utilizing goods and/or services for security and safety.

Article 1 paragraph (1) Law No. 8 of 1999 concerning Consumer Protection Labelization of halal food can guarantee that the food product is genuinely halal if labeling is carried out based on an MUI fatwa halal food product certification process. Therefore, producers that include halal labels on the food they produce are fully responsible for the statement they make [1].

Regulations on halal products already exist, but it is undeniable that they are still not widely popular, so people are still confused about getting truly guaranteed halal products. Because many products bear the sign of halal illegally, food and non-food processing, the halal status of products on the market is very vulnerable because the processing process is complex and involves many parties and other business actors [5].

Food Safety is a condition and effort needed to prevent Food from the possibility of contamination of biological, chemical, and other objects that can disturb, harm, and endanger human health and does not conflict with religion, belief, and culture of the community so that it is safe for consumption (Article 1 Paragraph 5 Food Law).

Food Safety is implemented to keep Food safe, hygienic, quality, nutritious, and does not conflict with the community's religion, belief, and culture. Food Safety is intended to prevent possible contamination of biological, chemical, and other objects that can harm and endanger human health. Food Sanitation is an effort to create and maintain a healthy and hygienic food condition free from the dangers of biological, chemical, and other contamination. Sanitation requirements are hygiene and health standards that must be met to ensure Food Sanitation. Quality food is food that meets safety criteria and has good nutritional content. The breadth of the relationship between food and various fields of life was also raised by those who discussed the debate on food security theory and policy, an important topic in a broader field [3][6].

Implementation of Halal Product Guarantee (JPH) according to Law No. 33 of 2014 based on; protection, justice, legal certainty, accountability and transparency, effectiveness and efficiency, and professionalism (Article 2 of the Halal Assurance Law). Article 4 of the Halal Guarantee Law stipulates that Products that enter circulate, and are traded in Indonesia's territory must be halal certified. The provisions of Article 4 are valid for 5 (five) years from the time the law was promulgated (Article 67 Paragraph 1 of the Halal Guarantee Law). Before this regulation came into effect, the types of certified halal products were regulated in stages (Article 67 Paragraph 2 of the Halal Guarantee Law). 
The purpose of the Halal Product Guarantee is to provide comfort, security, safety, and assurance of the availability of Halal Products for the public in consuming and using the Products; and increase added value for Business Actors to produce and sell Halal Products (Article 3 Letter a and b of the Halal Product Guarantee Law).

The implementation of Halal Product Guarantee is the Government's responsibility (Article 5 Paragraph (1) of the Halal Guarantee Law). The minister's implementation of the Halal Product Guarantee is carried out (Article 5 Paragraph (2) of the Halal Guarantee Law. What is meant by the minister here is the minister who manages government affairs in the religious sector (Article 1 Paragraph 15 of the Halal Guarantee Law). A Halal Product Guarantee Agency (BPJPH) is established, which is domiciled under and responsible to the Minister to implement Halal Product Guarantee. (Article 5 Paragraph 3 of the Halal Guarantee Law). If needed, BPJPH can form representatives in the regions. (Article 5 Paragraph 4 of the Halal Guarantee Law). Provisions regarding the duties, functions and organizational structure of BPJPH are regulated in a Presidential Regulation (Article 5 Paragraph (5) of the Halal Guarantee Law.

Based on this authority, it is known that BPJPH, which is authorized to issue halal certificates, is no longer MUI. MUI is one of the parties required by BPJPH to carry out its authority (Article 7 of the Halal Guarantee Law). The form of cooperation between BPJPH and MUI is Halal Auditor certification, product halalness, and LPH accreditation. MUI issues the determination of the halalness of a product in the form of a decision to determine the halal product (Article 10 of the Halal Guarantee Law).

\subsection{Discussion}

Research on existing data in BPOM shows that there are industrial facilities used by food business actors that do not meet standards. For example, it can be seen from table 1.

Table 1. Food Products that do not comply with the provisions

\begin{tabular}{clcc}
\hline No. & \multicolumn{1}{c}{ Types of TMK Findings } & $\begin{array}{c}\text { Total Amount } \\
\text { (ITEM) }\end{array}$ & $\begin{array}{c}\text { Economic Value } \\
\text { (IDR) }\end{array}$ \\
\hline 1 & The product is damaged & 71.764 & 327.049 .004 \\
\hline 2 & Expired & 281.684 & 691.546 .315 \\
\hline 3 & $\begin{array}{l}\text { TMK (Tidak Memenuhi Ketentuan/does not } \\
\text { meet the conditions) label }\end{array}$ & 472.399 & 1.187 .194 .272 \\
\hline 4 & Food without distribution authorization & 3.707 .002 & 3.411 .540 .903 \\
\hline 5 & Others (contains hazardous materials) & 471 & 3.656 .500 \\
\hline \multicolumn{4}{r}{ Source: BPOM data for 2018. }
\end{tabular}

The data above shows that business actors who do not meet the label requirements are 472,399 with an economic value of 1,187,194,272 rupiahs. The data shows that food labels that do not meet standards are still widely practiced in society. This case also includes the inclusion of a halal label without going through a certification process. It can be misleading, harmful, and detrimental to consumers. Food production that does not comply with standards can also harm the national economy. According to Lyons [7], the global food trade has an enormous impact on populations' health and nations' economies. According to WHO, around 600 million people become ill and 420,000 die each year from food-borne diseases. Losses in productivity and trade and treatment costs amount to US\$ 110 billion annually, mainly in low and middle-income countries. 
In this case, the producer is responsible for the consequences of the food it produces. Legal protection for food producers and consumers must be balanced. Thus, it will create business development in the processed food sector by paying more attention to food quality standards. If including a halal label that has not gone through the certification process, the producer can be sued based on illegal acts. The basis for the lawsuit is Article 1365 of the Civil Code. Acts against the law, in this case, are meant as acts against the law in the civil sector. The term "Acts against the Law (onrechmatige daad/tort)". Tort means a civil error that does not come from default.

The elements contained in Actions against the Law are an act; the act is against the law; there is an error on the perpetrator's part; there is a loss for the victim, and there is a causal relationship between actions and losses. So far, the assessment and the relative legal framework have only seen signs of difference in the way in which courts view the critical elements of tort legal action, namely the concept of damage, the existence of a causal relationship, and the burden of proof [8][9].

The regulatory model for the Indonesian Civil Code regarding illegal acts, as in other countries in the Continental European legal system. The model of liability in Continental European countries includes:

1) Responsibility with error elements (intentional and negligent), as contained in Article 1365 of the Civil Code.

2) Responsibility with an element of error, especially an element of negligence, as contained in Article 1366 of the Civil Code.

3) In a very limited sense, absolute liability (without error) is found in Article 1367 of the Civil Code.

Today tort law states that separate prosecution of offenses against the person is no longer necessary, given the growth and development of negligence laws. Nevertheless, there is a role for perpetual infringement for the person, and that the interests protected by the suit of infringement are not adequately included in negligence. Whatever convergence occurs between claims for infringement and negligence, there will continue to be different elements of the offense that are not known for negligence [10].

To create a balance between consumers and producers in the provision of healthy food, the government has obligations as regulated in Article 68 of the Food Law:

1) Guarantee the realization of the implementation of Food Safety in each Food chain in an integrated manner.

2) Establish Food Safety norms, standards, procedures, and criteria.

3) The Food Safety norms, standards, procedures, and criteria are carried out in stages based on the Food and Food business scale.

4) Obliged to develop and supervise the implementation of Food Safety norms, standards, procedures, and criteria

Food Safety has carried out through: a) Food Sanitation; b) Regulation of Food additives;

c) Regulation of Genetically Engineered Food Products; d) Regulation of Food Irradiation; e) Stipulation of Food Packaging standards; f) Providing Food Safety and Quality assurance; and g) Guarantee of halal products for those who are required.

Guarantee of halal products is one of the efforts to implement food safety. Based on Article 4 of the Halal Product Guarantee Law and Article 2 of the Government Regulation on Implementing Regulations on the Law on Halal Product Guarantee, it is stated that products that enter, circulate, and are traded in the territory of Indonesia must be halal certified. Products originating from prohibited materials are exempted from the obligation to be halal certified. The product must be declared non-halal. Business Actors are required to include non-halal 
information on the Products. It shows that all business actors who import, distribute and trade products in Indonesia's territory must carry out halal certification. Business actors who violate the halal production guarantee will be subject to administrative sanctions. Food safety is also an obligation for everyone involved in the food chain to control the risk of harm to food, whether it comes from materials, equipment, production facilities, or individuals. Food safety efforts for all people, which lead to efforts to improve the nutritional status of the community, must continuously be improved. Health is a human right and one of the elements of welfare that must be realized by the ideals of the Indonesian people as referred to in Pancasila and the Preamble to the 1945 Constitution of the Republic of Indonesia. Therefore, every activity and effort to improve public health to the highest degree is carried out based on non-discriminatory, participatory, protective, and sustainable principles 'that are very important for forming Indonesia's human resources, the nation's resilience and competitiveness, and national development.

\section{Conclusion}

Businesses that import, distribute, and trade products in Indonesia's territory must carry out halal certification. Business actors who violate the halal production guarantee will be subject to administrative sanctions. In addition, producers are obliged to carry out halal certification for their products as one of the business actors. If a business actor includes a label of things but does not go through the halal certification process, it can lead to error and loss to the consumer. Thus, they can be sued based on an illegal act.

\section{References}

[1] S. M. Badriyah, "Labelisasi Halal Sebagai Jaminan Kehalalan Produk Pangan,” J. Kosmik Huk., vol. 5, no. 1, pp. 14-28, 2005.

[2] N. N. Abd Aziz, N. A. A. Aziz, N. A. Abd Aziz, Z. Omar, and W. H. A. W. Hassan, "A review on the emergence and growth of halal studies," Procedia Econ. Financ., vol. 31, pp. 325-332, 2015.

[3] F. Burchi and P. De Muro, "From food availability to nutritional capabilities: Advancing food security analysis," Food Policy, vol. 60, pp. 10-19, 2016.

[4] R. W. Ashadi, "Halal science: an introduction," J. Halal Reseach, vol. 1, no. 1, pp. 32-35, 2015.

[5] M. Ilyas, "Sertifikasi dan Labelisasi Produk Halal Perspektif Maslahat," J. Al-Qadau Peradil. dan Huk. Kel. Islam, vol. 4, no. 2, pp. 357-376, 2018.

[6] F. Hasun, H. Tanjung, S. K. Wiryono, and M. A. Choudhury, "The Framework of Food Security and The Food Security Ecosystem: Tawhidi Perspective," Int. J. Halal Res., vol. 3, no. 1, pp. 42-59, 2021.

[7] J. Lyons, "Food safety standards \& regulations: A brief overview," Rentokil, Jul. 18, 2019. https://www.rentokil.com/blog/food-safety-standards/\#.YKW9S6gzaUn (accessed May 20, 2021).

[8] L. Squintani, “Tort-Law based Environmental Litigation: a Victory or a Warning?," J. Eur. Environ. Plan. Law, vol. 15, no. 3-4, pp. 277-280, 2018.

[9] S. M. Badriyah, A. Soemarmi, and S. Mahmudah, "The Model of Business Activities Legal Responsibility in Anticipation of Environmental Pollution Impact on Sea Fish as a Food Raw Material by Small and Medium Enterprises," in 3rd International Conference on Globalization of Law and Local Wisdom (ICGLOW 2019), 2019, pp. 30-33. 
[10] J. A. Devereux, "On not trespassing on trespass: In defence of separate torts of trespass to the person,” Tort Law Rev., vol. 26, no. 2, pp. 98-103, 2019. 